\title{
ESTUDO DA ATIVIDADE SÍSMICA EM SÃO CAETANO - PE EM 2007
}

\author{
Heleno Carlos de Lima Neto \\ Orientador: Dr. Joaquim Mendes Ferreira (UFRN) \\ 127 p. - Dissertação (Mestrado) - Defesa 06.03.2009
}

\begin{abstract}
RESUMO. Nesta dissertação foi estudada a atividade sísmica no município de São Caetano, estado de Pernambuco, Nordeste brasileiro, localizado próximo ao Lineamento Pernambuco. Lineamento Pernambuco é uma zona de cisalhamento Neoproterozóica de escala continental que deforma a província Borborema. A sismicidade estudada ocorreu numa ramificação para nordeste do Lineamento Pernambuco. A atividade sísmica em São Caetano iniciou em 2006 e no dia 20/05/2007 ocorreu, neste município, um sismo de magnitude 4,0 mb. Este é o sismo de maior magnitude que ocorreu no estado de Pernambuco. Este trabalho é decorrente da análise de dados coletados durante o período de monitoramento na região que foi de 01/02/2007 até 21/07/2007. Nesse monitoramento foi utilizado de seis até nove estações sismográficas digitais. Os dados coletados por essas estações foram analisados, objetivando a determinação dos hipocentros e do mecanismo focal composto. Foram utilizados 214 sismos, registrados em pelo menos três estações. Na determinação hipocentral, foi utilizado o programa HYP071, assumindo- se um modelo de semi-espaço, com os parâmetros: velocidade da onda $P\left(V_{p}\right)$ e razão $V_{p} N_{S}$, respectivamente, $5,90 \mathrm{~km} / \mathrm{s}$ e 1,70. Os hipocentros dos sismos ocorridos na região deste estudo acompanham uma ramificação para nordeste do Lineamento Pernambuco e possui aproximadamente $4 \mathrm{~km}$ de extensão e profundidade variando entre 2 até $8 \mathrm{~km}$. 0 mecanismo focal composto foi feito para um conjunto de 14 sismos selecionados. Nós primeiramente tentamos encontrar a solução do plano de falha considerando apenas a distribuição de polaridades utilizando o programa FPFIT. Os resultados foram: $43^{\circ} \pm 15^{\circ}$ para 0 azimute, $59^{\circ} \pm$ $9^{\circ}$ para o mergulho e $-142^{\circ} \pm 15^{\circ}$ para 0 rake. Nós também ajustamos o plano usando a distribuição hipocentral. Os resultados obtidos foram: $58^{\circ}$ para 0 azimute, $55^{\circ}$ para o mergulho. 0 valor do rake foi fixado em $-155^{\circ}$. Este resultado mostra um mecanismo de uma falha transcorrente dextral com uma componente normal. Esta dissertação mostra, mais uma vez, que existe uma boa correlação entre a sismicidade e falhas mapeadas na região próxima ao Lineamento Pernambuco e suas ramificações para nordeste.
\end{abstract}

ABSTRACT. In this dissertation we studied the seismic activity in the São Caetano county, Pernambuco State, Northeastern Brazil, located near the Pernambuco Lineament. The Pernambuco Lineament is a one of Neoproterozoic continental-scale shear zones that deforms the Borborema province. The seismicity occurred in a NE trending branch of Pernambuco Lineament. The seismic activity in São Caetano started in 2006 and in May $20^{\text {th }}, 2006$ a $4.0 \mathrm{~m}_{\mathrm{b}}$ earthquake hit there. This was the largest earthquake ever reported in Pernambuco State. This dissertation is the result of a campaign done in the period from February $1^{\text {st }} 2007$ to July $31^{\text {st }}$ 2007. In this campaign up to nine three-component digital seismographic stations were deployed and the collected data was used to determine hypocenters and focal mechanism. A total of 214 earthquakes, recorded at least by three stations, were analyzed. To determine hypocenters and time origin the HYP071 program was used assuming a half-space model with parameters: $V_{P}(P$-wave velocity) equal to $5.90 \mathrm{~km} / \mathrm{s}$ and the ratio $V_{P} N_{S} 1.70$, where $V_{S}$ is the $S$-wave velocity. The earthquakes hypocentral distribution was approximately $4 \mathrm{~km}$ long and agrees with the NE-SW direction of the Pernambuco Lineamento branch. Hypocenters depth range from 2 to $8 \mathrm{~km}$. The composed focal mechanism was made from a group of 14 selected earthquakes. We try firstly to find the fault plane solution matching the polarity distribution at stations, using the FPFIT program. The result was $43 \mathrm{deg} \pm 15$ deg for strike, $59 \mathrm{deg} \pm 9$ deg for dip and $-142 \mathrm{deg} \pm 15 \mathrm{deg}$ for rake. We also fitted a plane using the hypocentral distribution to obtain the dip and azimuth of the hypocentral distribution. The results obtained by this fit were 58 deg for the azimuth, $55 \mathrm{deg}$ for the dip and -155 deg for rake. This result shows a mechanism of a strike-slip dextral fault with a normal component. This dissertation shows, once more, that there is a good correlation between the seismic activity and geological features in the region near the Pernambuco Lineament and its NE branches. 